\title{
ANALISIS PERHITUNGAN HARGA POKOK PRODUKSI BERDASARKAN METODE FULL COSTING ( STUDI KASUS PADA UKM DIGITAL PRINTING PRABU )
}

\author{
Ilham Nurizki Fadli ${ }^{1)}$ \\ ilhamnurizki9@gmail.com, Akuntansi, Universitas Trilogi \\ Rizka Ramayanti ${ }^{2)}$ \\ rizka.ramayanti@universitas-trilogi.ac.id, Akuntansi, Universitas Trilogi
}

\begin{abstract}
ABSTRAK
Perhitungan harga pokok produksi berdasarkan metode Full Costing lebih tepat dan akurat. Dikarenakan metode full costing memasukkan seluruh komponen biaya yang digunakan dengan detail untuk proses produksi. Tujuan dari penelitian ini yaitu untuk menganalisis perbandingan perhitungan harga pokok produksi dengan metode Full Costing dan perhitungan harga pokok produksi UKM Digital Printing Prabu. Hasil penelitian memperlihatkan bahwa perhitungan harga pokok produksi berdasarkan metode full costing menunjukkan angka yang lebih tinggi dari perhitungan harga pokok produksi berdasarkan metode UKM Digital Printing Prabu. Harga pokok produksi dengan menggunakan metode full costing sebesar Rp 19.293,-. Sedangkan untuk hasil perhitungan dengan menggunakan metode UKM Digital Printing Prabu sebesar Rp 13.976,-. Hal ini disebabkan UKM Digital Printing Prabu hanya memasukkan biaya bahan baku flexi china saja, biaya tenaga kerja dan biaya overhead listrik saja. Dan tidak memasukkan biaya bahan baku lainnya seperti biaya tinta, biaya lem, dan biaya mata ayam, dan overhead lainnya seperti biaya penyusutan peralatan produksi, biaya sewa tempat, biaya solven, dan biaya tissue dalam penentuan harga pokok produksi.
\end{abstract}

\section{Kata Kunci : Harga Pokok Produksi, Biaya, Metode Full Costing}

\begin{abstract}
The calculation of the cost of production based on the full costing method is more precise and accurate. Because the full costing method includes all cost components used in detail for the production process. The purpose of this study is to analyze the comparison of the calculation of the cost of production with the full costing method and the calculation of the cost of production of UKM Digital Printing Prabu. The result showed that the calculation of the cost of production based on the full costing method showed a higher number than the calculation of the cost of production based on the UKM Digital Printing Prabu. Cost of production using the full costing method of Rp 19.293,-. While the calculation results using the UKM Digital Printing Prabu method are Rp 13.976,-. This is due to UKM Digital Printing Prabu only include the cost of flexi china raw materials, labor costs, and electricity overhead only. And does not include other raw material costs such as ink costs, glue costs, and chicken eye costs, and other costs such as costs for depreciation of production equipment, costs for renting space, solvent costs, and tissue costs in determining the costs of production.
\end{abstract}

\section{Keywords : Cost of production, Cost, Full costing method}




\section{PENDAHULUAN}

Dunia usaha atau bisnis yang terjadi pada waktu ini sudah berkembang sangat cepat, baik itu dalam bentuk perusahaan, CV, skala makro ataupun skala mikro. Banyak usaha atau bisnis yang berkembang begitu cepat sehingga menciptakan persaingan diantara usaha tersebut, dengan demikian perusahaan tersebut akan berkompetisi untuk mencapai posisi nomor satu dimata customernya, mulai dari kualitas produk yang dihasilkan sampai pelayanan yang diberikan oleh perusahaan.

Didalam suatu negara untuk menjalankan perekonomian dibutuhkan beberapa faktor, diantaranya yaitu Perusahaan, Usaha Kecil Menengah, dan Usaha Micro Kecil Menengah. Usaha Kecil Menengah menjadi bagian yang bisa menggerakkan perekonomian disuatu negara.Dimana menurut Muhammad Ikhsan yang dikutip pada https://economy.okezone.com/ pada tanggal 19 Juni 2020 sebagai ketua Asosiasi Ketua Asosiasi UMKM Indonesia menyatakan bahwa UMKM menyumbang sebanyak 60\% dari PBD Indonesia. Selain itu, menurut Bapenas (2016) nilai investasi Usaha Micro Kecil Menengah terus mengalami peningkatan rata-rata sebesar 10,6persen dalam periode 2011-2015. Kontribusi investasi Usaha Micro Kecil Menengah yang terbesar disumbangkan oleh usaha menengah $(56,4 \%)$ dan usaha kecil $(31,6 \%)$. Akan tetapi dari kontribusi yang besar tersebut, masih banyaknya Usaha kecil menengah yang setiap triwulannya mengalami penurunan produksi. Salah satu contoh pertumbuhan produksi Usaha Micro Kecil Menengah di Jakarta berdasarkan data BPS (2019) bahwa triwulan 1 sebesar 26,74\% ditriwulan 4 menjadi 17,59\%. dari hal tersebut dapat dilihat adanya penurunan jumlah Usaha Micro Kecil Menengah. Penurunan produksi terjadi salah satunya karena pengelolaan keuangan. Menurut Zimmerer dan Scarborough (2008) dalam penelitian Maghfirah, Mifta, dan Fazli Syam BZ (2016) salah satu kegagalan berwirausaha pada Usaha kecil menengah adalah penetapan hatga yang kurang tepat. Jadi jika penentuan harga tidak tepat maka perhitungan harga pokok produksi juga kurang tepat. Maka agar harga yang ditetapkan akurat seharusnya umkm menentukan harga pokok produksi dengan akurat.

Untuk Usaha Kecil Menengah menentukan harga pokok produksi sangat penting dimana salah satu manfaatnya yaitu untuk menentukan harga jual suatu produk. Terdapat tiga bagian atau golongan yang bisa dipakai untuk menentukan harga pokok produksi. Pertama adalah biaya bahan baku, Kedua biaya karyawan atau tenaga kerja, dan terakhir biaya overhead. Ketika harga pokok produksi sudah didapat, maka langkah selanjutnya yaitu bisa menetapkan harga jual suatu barang yang sudah diproduksi.

Penelitian Rahmi (2015) tentang biaya produksi dimana dilakukan pada kasus Usaha Kecil Menengah Tahu Di Daerah Natar Lampung Selatan menunjukkan bahwa terdapat perbedaan antara perhitungan yang dilakukan oleh Usaha Micro Kecil Menengah dengan peneliti. Dimana ada ketidak akuratan dalam perhitungan biaya produksi. Begitu juga dalam penelitian Bintang, dkk (2016) dalam penetapan harga jual pada CV Salwa Meubel. Dimana dalam perhitungan harga pokok produksi untuk mendapatkan harga jual juga terdapat perbedaan yang dilakukan analis peneliti dengan yang dilakukan cv salwa meubel daerah Sukabumi. Maka dari itu perlu melakukan perhitungan harga pokok produksi secara akurat. Dari informasi harga pokok produksi selanjutnya dapat menghitung harga jual. Dimana untuk menentukan harga jual produk bisa ditentukan dengan harga yang tidak terlalu rendah atau tinggi. Sehingga harga tersebut dapat bersaing dengan yang lainnya dan tetap menghasilkan laba yang sesuai keinginan.

Beberapa penelitian tersebut berfokus pada daerah luar Jakarta. Berdasarkan BPS (2019) Pertumbuhan Produksi Usaha Micro Kecil Menengah dikawasan Jakarta mengalami peningkatan sebesar 26,25\% dari tahun 2017 ke 2018, oleh karena itu penelitian ini tertarik meneliti Usaha Micro Kecil Menengah daerah Jakarta. Salah satu Usaha Micro Kecil Menengah di Jakarta adalah Digital Printing Prabu. Digital Printing Prabu bentuk UKM yang bergerak di sektor 
percetakan dan produk yang paling banyak terjual yaitu print banner atau spanduk dengan bahan cetak flexi china. Penelitian ini akan menganalisis harga pokok produksi untuk produk spanduk atau banner memakai bahan cetak flexi china dengan menggunakan file yang sudah siap dicetak , yang di produksi oleh Digital Printing Prabu.

Sejauh ini untuk menentukan harga pokok produksi, pihak Digital Printing Prabu belum memasukkan seluruh komponen biaya yang digunakan dengan detail untuk proses produksi sehingga informasi yang dihasilkan belum akurat dan kurang tepat untuk menetapkan (HPP) harga pokok produksi dan harga jualnya. UKM Digital Printing Prabu dalam menentukan harga pokok produksi yaitu melalui cara mentotalkannya biaya bahan baku, biaya karyawan untuk memproduksi cetakan atau print banner, dan pengeluaran uang untuk listrik, sedangkan biaya overhead lainnya baik biaya variabel mapun biaya tetap belum diperhitungkan, sehingga harga pokok produksi yang dihasilkan belum memperlihatkan harga pokok produksi yang sebenarnnya, hal tersebut bisa mempengaruhi harga penjualannya.

Oleh sebab itu, supaya tidak terjadi kesalahan saat proses menentukan harga pokok produksi pada UKM Digital Printing Prabu diperlukan suatu metode yang tepat. Metode tersebut yaitu metode full costing, karena metode full costing merupakan metode yang memperhitungkan semua komponen biaya produksi baik untuk bersifat variabel maupun tetap terhadap barang produksi.

\section{TINJAUAN PUSTAKA \\ Akuntansi Biaya}

Mulyadi (2016) pengertian akunntansi biaya yaitu proses mencatat, pengklasifikasian, meringkas dan menyajiakan biaya, penjualan dan membuat suatu jasa atau barang, dengan cara yang sudah ditentukan dan penafsiran terhadapnya. Untuk objek yang bersangkutan pada akuntansi biaya yaitu biaya.

Pendapat dari V. Wiratna Sujarweni (2019) akuntansi biaya yaitu pengendalian biaya yang terjadi pada perusahaan yang menghasilkan informasi biaya untuk di gunakan pihak manajemen dalam mengambil keputusan. Informasi ini meliputi biaya bahan baku, biaya tenaga kerja langsung, biaya overhead pabrik, penyimpanan dan penjualan produk jadi.

Akuntansi biaya sangat penting untuk keperluan suatu usaha, dimana akuntansi biaya ini bisa digunakan dalam proses untuk menentukan biaya apa saja yang diperoleh untuk menciptakan suatu produk. Selain itu biaya akan dibagi menjadi beberapa golongan atau bagian dan juga penyajian biaya dilakukan dengan cara yang sudah ditentukan.

\section{Tujuan Akuntansi Biaya}

Mulyadi (2016), menyatakan bahwa terdapat 3 tujuan yang dimiliki oleh akuntansi biaya diantaranya yaitu :

1. Penetapan Kos barang

Untuk memenuhi kebutuhan kos barang, akuntansi biaya melakukan pencatatan, mengklasifikasikan, dan merangkum biaya - biaya untuk membuat suatu produk dan penyediaan jasa.

Dalam proses pencatatan harus dilakukan secara tepat dan akurat, sehingga nantinya akan menghasilkan informasi yang benar dalam menentukan kos produk. Setiap biaya yang dicatat digolongkan agar lebih memudahkan dalam proses penentuan kos produk.

2. Pengendalian Biaya 
Pertama-tama penentuan biaya harus sudah ditetapkan terlebih dahulu untuk membuat suatu barang. Setelah biaya sudah ditetapkan, maka akuntansi biaya akan mengecek apakah pengeluaran biaya yang dilakukan pada saat itu sudah sesuai atau belum. Jika belum akuntansi biaya akan menganalisis terhadap penyebab-penyebab terjadinya ketidaksesuaian biaya yang sudah dikeluarkan tersebut, sehingga biaya bisa dikendalikan.

3. Pengambilan Keputusan Khusus

Hal-hal yang perlu diperhatikan dalam pengambilan keputusan khusus adalah informasi yang relevan dari biaya-biaya yang sudah ditentukan sebelumnya, dan informasi biaya ini bersangkutan dengan informasi biaya pada masa yang akan datang, sehingga seseorang bisa lebih mudah untuk mengambil keputusan khusus.

\section{Pengertian Biaya}

Menurut Hansen dan Mowen (2019) biaya merupakan kas atau nilai setara kas yang dikorbankan buat memperoleh jasa dan barang yang diharapkan memberikan manfaat pada masa sekarang atau yang akan datang untuk organisasi.

Mulyadi (2016) pengertian secara luas menyatakan bahwa biaya yaitu pengorbanan sumber ekonomi, dimana pengukurannya dengan menggunakan uang, yang sudah terjadi atau yang memungkinkan untuk terjadi pada tujuan tertentu. Terdapat empat bagian inti pada definisi biaya yang sudah disebutkan sebelumnya, diantaranya merupakan : biaya adalah pengorbanan sumber ekonomi, pengukurannya menggunakan uang, baik sudah terjadi atau memungkinkan untuk terjadi, pengorbanan yang terjadi diperuntukan tujuan yang sudah ditentukan.

\section{Klasifikasi Dan Penggolongan Biaya}

Menurut Hansen dan Mowen (2019) biaya dikelompokkan menjadi 2 golongan fungsional pokok diantaranya yaitu : nonproduksi dan produksi. Biaya Produksi merupakan biaya yang berhubungan dalam proses terbentuknya produk dan jasa yang disediakan. Sedangkan biaya nonproduksi yaitu biaya yang tidak berkaitan pada saat proses terbentuknya produk barang atau jasa yang disediakan.

Mulyadi (2016), biaya digolongkan menjadi 5 golongan :

1. Menurut Objek Pengeluaran

Dasar penggolongan biaya ini ditentukan oleh nama objek pengeluaran. Misalnya untuk objek pengeluaran bahan baku, oleh karena itu seluruh pengeluaran yang berkaitan dari bahan baku tersebut dibilang "biaya bahan baku". Contoh menggolongkan biaya terhadap objek pengeluaran pada jenis usaha percetakan yaitu : biaya bahan flexi china, biaya karyawan atau tenaga kerja, biaya penyusutan, biaya tinta, biaya solven, dan biaya internet.

2. Menurut Fungsi Pokok dalam Perusahaan

Dalam perusahaan manufaktur, ada 3 fungsi penting untuk menjalankan perusahaan diantarnya pemasaran, produksi, umum dan administrasi.

Biaya pemasaran yaitu biaya untuk difungsikan buat melakukan aktivitas pemasaran suatu barang yang sudah diproduksi. Biaya produksi adalah biaya digunakan saat membuat bahan baku menjadi produk yang siap untuk diperjualkan. Sedangkan biaya umum $\&$ administrasi yaitu digunakan untuk pengorganisasian aktivitas produksi dan pemasaran.

3. Menurut Hubungan Biaya dengan Sesuatu yang dibiayai.

Sesuatu yang dibiayai bisa dalam bentuk departemen atau produk. Untuk kaitannya pada sesuatu yang dibiayai, biaya bisa dibagi untuk 2 bagian yaitu biaya tidak langsung dan biaya langsung. Biaya langsung merupakan biaya yang didapat jika ada 
yang harus dibiayai. Dan misalnya tidak ada yang dibiayai maka biaya langsung tidak terjadi. Sedangkan untuk biaya tidak langsung bisa dikategorikan sebagai biaya overhead pabrik.

4. Menurut Perilakunya Biaya dalam Hubungannya dengan Perubahan Volume Aktivitas.

Biaya digolongkan untuk empat jenis, diantaranya yaitu : Biaya Variabel, Biaya Semi Variabel, Biaya Semifixed, Biaya Tetap. Biaya variabel yaitu biaya keseluruhan total mengikuti keadaan kegiatan, jika kegiatan berubah maka biaya tersebut juga akan berubah.. Biaya semi variabel yaitu biaya yang berubah tidak sesuai dengan apa yang sudah dilakukan dalam kegiatan produksi. Biaya semifixed yaitu biaya yang tetap dalam kegiatan tertentu, dan berubah sesuai kegiatan yang sudah dilakukan selama proses produksi. Biaya tetap yaitu biaya yang ketika diperhitungkan sudah tidak berubah lagi dan bersifat tetap.

5. Menurut Jangka Waktunya

Dalam jangka waktu pemanfaatannya, terdapat 2 kategori biaya diantaranya adalah Pengeluaran Pendapatan (revenue expenditures) dan pengeluaran modal (capital expenditures). Pengeluaran pendapatan adalah biaya yang memiliki manfaat untuk periode akuntansi jika ada pengeluaran didalam periode tersebut, dan pengeluaran modal yaitu biaya yang memiliki manfaat untuk 1 periode akuntansi (dalam jangka waktu 1 tahun kalender)

\section{Harga Pokok Produksi}

Harga pokok produksi diperlukan sekali oleh pihak manajemen perusahaan dan bagian luar perusahaan. Maka dari itu akuntansi biaya mencatat, menggolongkan beserta merangkum biaya membuat produk. Pendapat dari Hansen dan Mowen (2019) harga pokok produksi yaitu memperhitungkan jumlah biaya barang yang diselesaikan selama periode berjalan. Mulyadi (2016) berpendapat bahwa "Harga pokok produksi adalah sejumlah biaya yang terjadi untuk mengolah bahan baku menjadi produk jadi yang siap untuk dijual".

Dari pengertian tersebut maka dari itu biaya yang dimasukkan yaitu biaya pada saat proses produksi, selama proses produksi itu sendiri terdapat biaya-biaya bahan baku, biaya karyawan untuk membuat produk tersebut, dan juga biaya diluar bahan baku dan karyawan atau biasa yang disebut dengan biaya overhead. Biaya overhead ini terdapat dua macam yaitu overhead variabel dan tetap.

\section{Unsur - Unsur Harga Pokok Produksi}

Menurut Hansen dan Mowen (2019) terdapat tiga elemen biaya yang berkaitan dengan biaya produksi atau harga pokok produksi. Yang pertama adalah bahan langsung yaitu bahan yang bisa dicari secara langsung pada produk dan jasa yang lagi dibuatkan menjadi produk/jasa. Elemen kedua adalah tenaga kerja langsung yaitu tenaga kerja langsung yang bisa dicari secara langsung pada barang dan jasa yang lagi dibuatkan menjadi produk/jasa. Dan yang terakhir adalah overhead yaitu seluruh biaya produksi selain biaya tenaga kerja langsung dan bahan langsung.

Menurut Mulyadi (2016) unsur-unsur harga pokok produksi yaitu : biaya bahan baku, biaya tenaga kerja, dan biaya overhead.Bahan baku adalah bahan untuk membuat suatu produk, untuk mendapatkan bahan baku bisa dengan berbagai cara mulai dari pengolahan sendiri, membeli disuatu pasar atau market dan juga impor dari luar negeri. Selain itu biaya pengeluaran lainnya juga dimasukkan seperti biaya gudang jika ada bahan baku yang perlu dimasukkan kedalam gudang, dan biaya perolehan lainnya. 
Biaya tenaga kerja atau bisa juga disebut dengan karyawan adalah orang yang bertugas untuk membuat suatu produk mulai dari bahan mentah hingga produk jadi. Biaya karyawan wajib dimasukkan kedalam perhitungan harga pokok produksi disuatu perusahaan.

Biaya overhead pabrik adalah biaya produksi diluar dari biaya karyawan (tenaga kerja) dan bahan baku. Ada beberapa contoh bisa dikategorikan kedalam biaya overhead pabrik, diantaranya yaitu biaya bahan pembantu untuk sebuah produk, biaya perawatan mesin, biaya karyawan tidak langsung, biaya penyusutan, biaya asuransi, biaya listrik dan lain sebagainya..

\section{Manfaat Harga Pokok Produksi}

Manfaat harga pokok produksi menurut Mulyadi (2016), yaitu sebagai berikut :Menentukan harga jual produk, memantau realisasi biaya produksi, menghitung laba atau rugi bruto periodik tertentu, menentukan harga pokok persediaan produk jadi dan produk dalam proses yang disajikan dalam neraca.

Setelah harga pokok produksi sudah didapat, maka langkah selanjutnya yaitu bisa menetapkan harga jual suatu barang atau jasa. Dari informasi harga pokok produksi dalam menetapkan harga jual suatu barang atau jasa bisa ditetapkan dengan harga yang tidak terlalu rendah atau tinggi. Sehingga harga tersebut dapat bersaing dengan yang lainnya dan tetap menghasilkan laba yang sesuai keinginan.

Untuk biaya produksi sebelumnya dibuat perencanaan terlebih dahulu, apa saja yang akan dilakukan untuk proses pembuatan produksi suatu barang. Informasi perhitungan biaya produksi ini diperlukan oleh pihak manajemen. Akuntansi biaya berguna untuk menyatukan informasi biaya apa saja yang keluar pada saat proses produksi dan juga untuk melihat apakah dalam pembuatan produk mengeluarkan total biaya yang sesuai dengan perencanaan yang sudah dibuat.

Dapat mengihitung profit atau rugi dalam periode tertentu, dalam poin ini harga pokok produksi bisa digunakan untuk mengetahui apakah kegiatan pembuatan produk dan penjualan perusahaan dalam jangka waktu yang sudah ditentukan bisa menghasilkan kerugian dan menghasilkan profit. Informasi profit dan rugi ini berguna untuk mengetahui kontribusi suatu barang atau jasa guna menutup biaya nonproduksi sehingga bisa mengetahui apakah rugi atau profit.

Selain itu harga pokok produksi juga bermanfaat untuk menetapkan harga pokok persediaan barang jadi dan dalam proses yang dituangkan dalam neraca. Pada pertanggungjawaban pihak manajemen tentang keuangan dalam jangka waktu tertentu, manajemen harus menyiapkan laporan keuangan seperti laporan laba rugi sampai neraca.

\section{Metode Penentuan Harga Pokok Produksi}

Metode Full Costing, pendapat dari V.Wiratna Sujarweni (2019) Full Costing yaitu cara perhitungan yang berguna menetapkan harga pokok produk, dengan membebankan seluruh biaya produksi tetap maupun variabel pada barang yang dibuatkan. Metode ini sering dikenal dengan absortion atau conventional Costing.

Mulyadi (2016) menyatakan bahwa, "Full costing adalah cara penetapan kos produksi yang memperhitungkan semua bagian biaya produksi terhadap suatu proses pembuatan produk, yang terdiri dari biaya bahan baku, biaya tenaga kerja langsung, dan biaya overhead pabrik, baik yang bersifat tetap ataupun variabel.

Maka dari itu kos produksi berdasarkan metode full costing terdapat dari unsur biaya produksi diantaranya yaitu:

$\begin{array}{ll}\text { Biaya bahan baku } & \text { AAA } \\ \text { Biaya tenaga kerja langsung } & \text { AAA } \\ \text { Biaya overhead pabrik variabel } & \text { AAA } \\ \text { Biaya } \text { overhead pabrik tetap } & \text { AAA }+ \\ \text { Biaya produksi } & \text { AAA }\end{array}$


Penetapan harga pokok produk melalui metode full costing terdiri dari biaya bahan baku yaitu biaya untuk bahan baku yang akan dipakai guna membuat suatu barang, setelah itu biaya tenaga kerja merupakan biaya yang digunakan untuk membayar orang yang bekerja untuk membuat suatu produk tersebut. dan yang terakhir adalah biaya overhead yaitu biaya diluar biaya tenaga kerja dan biaya bahan baku. Biaya overhead terdapat dua macam bagian, yang pertama adalah biaya overhead tetap dan yang kedua adalah biaya overhead variabel dimana biaya overhead variabel ini yaitu biaya yang berubah tergantung dari perubahan volume kegiatan dalam produksi.

Metode Variabel Costing, Menurut V. Wiratna Sujarweni (2019) Variabel Costing merupakan cara perhitungan untuk menetapkan harga pokok produksi dengan hanya memperhitungkan biaya produksi variabel saja. Menurut Mulyadi (2016), "Variable costing adalah metode penetapan kos produksi yang hanya memperhitungkan biaya produksi yang bersifat variabel untuk kos produksi, perhitungannya bisa didapatkan dari biaya bahan baku, biaya tenaga kerja langsung, dan biaya overhead pabrik variabel.

Maka dari itu kos produksi berdasarkan metode variable costing terdapat dari unsur biaya produksi diantaranya yaitu:

$\begin{array}{ll}\text { Biaya bahan baku } & \text { AAA } \\ \text { Biaya tenaga kerja langsung } & \text { AAA } \\ \text { Biaya overhead pabrik variabel } & \text { AAA + } \\ \text { Biaya produksi } & \text { AAA }\end{array}$

Penentuan harga pokok produk dengan menggunakan variabel costing terdapat dari biaya bahan baku, biaya tenaga kerja atau karyawan, dan juga biaya overhead. Yang menjadi perbedaan dari perhitungan full costing yaitu variabel costing hanya memasukkan biaya overhead yang hanya berperilaku variabel, untuk overhead tetap tidak dimasukkan ke dalam metode variabel costing.

\section{Sistem Pengumpulan Harga Pokok Produksi}

Dalam sistem pengumpulan harga pokok produksi terdapat 2 jenis sistem, yang pertama adalah harga pokok proses dan yang kedua adalah harga pokok pesanan. Menurut V.Wiratna Sujarweni (2019) harga pokok proses yaitu perhitungan harga pokok produksi berdasarkan biaya yang dibuatkan menjadi suatu produk atau barang jadi dalam periode tertentu dibagi unit produksi. Sedangkan harga pokok pesanan merupakan cara perhitungan harga pokok produksi didasari oleh pesanan dari konsumen.

Pendapat dari Hansen dan Mowen (2019) harga pokok pesanan yaitu perusahaan yang bergerak pada industri yang didasari oleh pesanan, memproduksi banyak jenis barang atau jasa yang memiliki perbedaan satu sama lainnya. Sedangkan harga pokok proses dimana perusahaan yang membuat suatu barang yang memiliki persamaan secara besar-besaran.

\section{METODE PENELITIAN Jenis Dan Sumber Data}

Dalam penelitian dilakukan ini data yang diterapkan yaitu data kualitatif, data kualitatif adalah sebuah analisis terhadap perusahaan. Sedangkan untuk sumber data, untuk melakukan penelitian ini memakai data primer, adalah untuk mendapatkan penjelasan-penjelasan dan informasi secara langsung dari UKM Digital Printing Prabu tentang penelitian yang sedang 
dilakukan. Yang kedua yaitu menggunakan data sekunder dimana data yang didapat berasal dari studi pustaka dan literatur.

\section{Teknik Pengambilan Sampel}

Teknik pengambilan sampel pada penelitian ini adalah purposive sampling, menurut Sugiyono (2010) purposive sampling merupakan teknik pengambilan sampel sumber data dengan pertimbangan tertentu. Contoh dari pengambilan sampel ini adalah seseorang yang dipercaya memiliki pengetahuan mengenai sesuatu yang kita butuhkan, dan bisa jadi orang tersebut bertugas sebagai pemimpin perusahaan dimana akan lebih mudah peneliti untuk menjelajahi obyek dan keadaan sosial yang diteliti. Untuk penelitian ini pimpinan UKM Digital Printing Prabu adalah seseorang yang menginformasikan data yang dibutuhkan untuk penelitian yang dilakukan.

\section{Teknik Pengumpulan Data}

Proses yang dilakukan untuk mengumpulkan data yaitu melakukan wawancara pada pemilik atau pimpinan dari UKM Digital Printing Prabu untuk mendapatkan data yang dibutuhkan dalam pembahasan harga pokok produksi.

Dokumentasi, Dalam penelitian ini dokumen yang berbentuk tulisan seperti melakukan pencatatan terhadap data-data mengenai harga pokok produksi, mulai dari pencatatan biaya bahan baku sampai tahap penyelesaian produksi pada UKM Digital Printing Prabu.

Studi Pustaka, Pada teknik pengumpulan data melalui studi pustaka, maka dapat dilakukan beberapa cara seperti membaca dan mempelajari buku dan jurnal penelitian yang berhubungan dengan analisis harga pokok produksi.

\section{HASIL DAN PEMBAHASAN \\ Perhitungan Harga Pokok Produksi Banner/Spanduk Berdasarkan Metode UKM Digital Printing Prabu}

Pada penelitian ini bahan baku yang digunakan yaitu bahan baku flexi china. Bahan baku terdapat dibagian printing, karena pada saat proses mencetak bahan baku akan langsung dimasukkan kedalam mesin cetak dan proses pencetakan akan langsung dikerjakan. Bahan baku flexi china yang digunakan dalam proses produksi dengan menggunakan file yang sudah siap dicetak di UKM Digital Printing Prabu pada saat bulan Januari sampai bulan Maret 2020 adalah 1553,2 m2. Untuk harga bahan baku flexi china itu sendiri yaitu seharga Rp 7.000,- per meter persegi (m2), jadi jika ditotalkan dengan pemakaian bahan pada saat itu sebesar 1553,2 m2 x Rp 7.000,- = Rp 10.872.400

Tenaga kerja yang berada di UKM Digital Printing Prabu yaitu berjumlah 3 orang karyawan yang dibagi menjadi bagian deskprint, bagian printing, dan bagian finishing, yang pertama bertugas sebagai deskprint yang melayani customer, selanjutnya karyawan yang kedua bertugas mengoperasikan mesin cetak, setelah itu karyawan yang ketiga membantu merapihkan hasil cetakan seperti mengelem cetakan, membuat lubang (mata ayam) di banner tersebut dan lain sebagainya. Untuk sistem pembiayaannya itu sendiri Digital Printing Prabu menerapkan harga sebesar Rp 2000,- per meter persegi (m2) dari hasil cetakannya tersebut. Jadi selama bulan Januari 2020 sampai Maret 2020, UKM Digital Printing Prabu memproduksi banner/spanduk dengan bahan flexi china sebanyak 1553,2 m2, 1553,2 m2 x Rp 2000,- = Rp 3.106.400,- x 3 orang $=$ Rp 9.319.200,-

Selama bulan Januari 2020 sampai Maret 2020 UKM Digital Printing Prabu memproduksi cetakan banner/spanduk dengan bahan flexi china sebanyak 1553,2 m2. Untuk perhitungan harga pokok produksi berdasarkan dari UKM Digital Printing Prabu biaya 
overheadnya yaitu hanya menghitungkan biaya listrik saja perbulannya, dimana besaran harga listrik tersebut dalam pemakaian oleh UKM Digital Printing Prabu dari bulan Januari sampai Maret 2020 sebesar Rp 1.516.000,-

Tabel 1. Biaya Selama Proses Alur Produksi Berdasarkan UKM Digital Printing Prabu

\begin{tabular}{|c|c|c|c|}
\hline \multirow{2}{*}{ Alur Produksi } & \multicolumn{3}{|c|}{ Biaya } \\
\hline & Bahan Baku Langsung & Tenaga Kerja Langsung & Overhead \\
\hline Bagian & - & Rp 3.106 .400 & - \\
\hline \multicolumn{4}{|l|}{ Penjualan/Deksprint } \\
\hline Bagian Printing & Rp 10.872 .400 & Rp 3.106.400 & - \\
\hline Bagian Finishing & - & Rp 3.106.400 & - \\
\hline Listrik & - & - & Rp 1.516.000 \\
\hline Total Biaya & Rp 10.872 .400 & Rp 9.319.200 & Rp 1.516.000 \\
\hline \multirow[t]{2}{*}{ Unit Produksi } & $1553,2 \mathrm{~m} 2$ & $1553,2 \mathrm{~m} 2$ & $1553,2 \mathrm{~m} 2$ \\
\hline & Rp 7.000 & Rp 6.000 & Rp 976 \\
\hline \multicolumn{2}{|c|}{ Harga Pokok Produksi Per Unit } & \multicolumn{2}{|c|}{ Rp 13.976,- per meter (m2) } \\
\hline \multicolumn{2}{|l|}{ Harga Jual } & \multicolumn{2}{|c|}{ Rp 25.000,- per meter (m2) } \\
\hline \multicolumn{2}{|l|}{ Keuntungan } & \multicolumn{2}{|c|}{ Rp 11.024,- per meter (m2) } \\
\hline
\end{tabular}

Sumber: UKM Digital Printing Prabu Bulan Januari-Maret 2020 diolah.

Pada tabel 1 menjelaskan bahwa alur produksi pada bagian deksprint terdapat biaya tenaga kerja langsung yang berjumlah satu orang dengan besaran Rp 3.106.400. sedangkan pada bagian printing terdapat biaya bahan baku langsung dengan besaran $\mathrm{Rp} 10.872 .400$, dan biaya tenaga kerja yang berjumlah satu orang dengan besaran Rp 3.106.400. Untuk bagian finishing terdapat biaya tenaga kerja langsung sebesar Rp 3.106.400 dimana pada bagian ini hanya terdapat satu orang karyawan saja. Dan pada biaya overhead disini terdapat biaya lisrik dengan jumlah Rp 1.516.000. Sehingga total untuk biaya bahan baku sebesar Rp 10.872.400, total biaya tenaga kerja $\mathrm{Rp}$ 9.319.200, dan biaya overhead sebesar $\mathrm{Rp}$ 1.516.000, masing-masing dibagi dengan unit produksi 1553,2 m2 maka besarannya akan menjadi Rp 7.000 untuk bahan baku, Rp 6000 untuk tenaga kerja, dan Rp 976 untuk biaya overhead. Jika ditotalkan akan mendapatkan besaran Harga Pokok Produksi per unit Rp 13.976,-- per meter (m2). Dengan harga jual Rp 25.000 maka akan mendapatkan keuntungan sebesar Rp 11.024,- per meter (m2).

\section{Perhitungan Harga Pokok Produksi Banner/Spanduk Berdasarkan Metode Full Costing}

Didalam penentuan harga pokok produk berdasarkan cara dari Full Costing, biaya yang dimasukkan yaitu biaya bahan baku, biaya karyawan/tenaga kerja, dan biaya overhead. Biaya overhead yang dimasukkan kedalam proses hitung ini meliputi biaya overhead bersifat variabel dan tetap dalam proses pembuatan suatu produk.

Dalam melakukan penelitian ternyata UKM Digital Printing Prabu pada proses pencetakan banner atau spanduk terdapat biaya bahan baku lainnya dan overhead. Biaya bahan baku lainnya dan overhead ini sebelumnya tidak dimasukkan ke dalam perhitungan biaya proses produksi oleh pihak UKM Digital Printing Prabu. Dan Karena deksprint bukan bagian produksi 
maka biaya tenaga kerja yang dibebankan ke produksi menjadi 2 orang saja yaitu bagian printing dan finishing. Oleh karena itu berikut akan dirincikan untuk biaya bahan baku lainnya, tenaga kerja dan overhead produksi selama bulan Januari 2020 sampai bulan Maret 2020.

Tabel 2. Biaya Selama Proses Alur Produksi Berdasarkan Full Costing

\begin{tabular}{|c|c|c|c|}
\hline \multirow{2}{*}{ Alur Produksi } & \multicolumn{3}{|c|}{ Biaya } \\
\hline & Bahan Baku Langsung & Tenaga Kerja Langsung & Overhead \\
\hline $\begin{array}{l}\text { Bagian Produksi } \\
\text { (printing\&finishing) }\end{array}$ & & & \\
\hline Bagian Printing & - & Rp 3.106.400 & - \\
\hline$>$ Biaya Flexi China & Rp 10.872.400,- & - & - \\
\hline$>$ Biaya Solven & - & - & $\mathrm{Rp} 450.000$ \\
\hline$>$ Biaya Tinta & Rp 3.850.000 & - & - \\
\hline$>$ Biaya Tissue & - & - & Rp 140.000 \\
\hline $\begin{array}{l}\text { Biaya Penyusutan } \\
\text { Mesin Cetak }\end{array}$ & - & - & $\operatorname{Rp} 2.500 .000$ \\
\hline Bagian Finishing & - & Rp 3.106.400 & - \\
\hline$>$ Biaya Lem & Rp 640.000 & - & - \\
\hline$>$ Biaya Mata Ayam & Rp 85.000 & - & - \\
\hline $\begin{array}{l}\text { Biaya Penyusutan } \\
\text { Matras/pembolong }\end{array}$ & - & - & Rp 131.250 \\
\hline $\begin{array}{ll}\text { Biaya } & \text { Listrik } \\
\text { Produksi } & \end{array}$ & - & - & Rp 992.291 \\
\hline $\begin{array}{ll}\text { Sewa } & \text { Tempat } \\
\text { Produksi } & \end{array}$ & - & - & Rp 4.090.909 \\
\hline Total Biaya & Rp 15.447.400,- & Rp 6.212.800,- & $\operatorname{Rp} 8.304 .450$ \\
\hline Unit Produksi & $1553,2 \mathrm{~m} 2$ & $1553,2 \mathrm{~m} 2$ & $1553,2 \mathrm{~m} 2$ \\
\hline & Rp 9.946 & $\operatorname{Rp} 4.000$ & Rp 5.347 \\
\hline Harga Pokok Produks & i Per Unit & Rp 19.293,- per meter $(\mathrm{n}$ & \\
\hline Harga Jual & & Rp 25.000,- per meter $(\mathrm{n}$ & \\
\hline Keuntungan & & Rp 5.707,- per meter $(\mathrm{m} 2$ & \\
\hline
\end{tabular}

Sumber: UKM Digital Printing Prabu Bulan Januari-Maret 2020 diolah. 


\section{Perbandingan Harga Pokok Produksi Banner Berdasarkan Metode UKM Digital Printing Prabu dan Metode Full Costing}

Hasil yang telah dihitung melalui kedua cara metode tersebut mengalami perbedaan. Tentunya hal ini dipengaruhi oleh cara penjumlahan yang telah dilakukan dari masing-masing metode. Untuk cara penentuan harga pokok produksi berdasarkan metode UKM Digital Printing Prabu. Pihak UKM Digital Printing Prabu memasukkan biaya bahan baku, biaya karyawan atau tenaga kerja, dan juga biaya overhead. Dimana biaya bahan baku hanya memasukkan biaya flexi china saja, untuk biaya tenaga kerja memasukkan semua tenaga kerjanya yaitu 3 orang, dan biaya overhead hanya dimasukkan untuk biaya listrik saja dalam proses perhitungan harga pokok produksi berdasarkan metode UKM Digital Printing Prabu.

Sedangkan untuk metode full costing, biaya yang dimasukkan kedalam proses perhitungan yaitu biaya bahan baku, biaya karyawan atau tenaga kerja, dan biaya overhead. Yang membedakannya disini yaitu biaya overhead tidak hanya biaya listrik saja, melainkan terdapat biaya penyusutan alat-alat produksi, biaya listrik, biaya sewa tempat, biaya solven, dan biaya tissue. Untuk biaya tenaga kerja karena deksprint bukan bagian produksi maka biaya yang dibebankan ke produksi menjadi 2 orang saja yaitu bagian printing dan finishing. biaya bahan bakunya terdapat biaya flexi china, biaya tinta, biaya lem, dan biaya mata ayam. Sehingga besaran harga pokok produksi mengalami perbedaan. Berikut akan dirincikan kedalam tabel untuk perbandingan harga pokok produksi banner berdasarkan metode UKM Digital Printing Prabu dengan metode Full Costing.

Tabel 3. Perbandingan Harga Pokok Produksi

\begin{tabular}{ll}
\hline \multicolumn{1}{c}{ Jenis Metode } & \multicolumn{1}{c}{ Harga Pokok Produksi } \\
\hline Metode Full Costing & Rp 19.293,- \\
Metode UKM Digital Printing Prabu & Rp 13.976,- \\
\hline Selisih & Rp 5.317,- \\
\hline
\end{tabular}

Sumber: UKM Digital Printing Prabu Bulan Januari-Maret 2020 diolah.

Pada tabel 3 menjelaskan bahwa harga pokok produksi dengan menggunakan metode full costing menunjukkan angka yang lebih besar yaitu Rp 19.293,--. Sedangkan untuk hasil perhitungan dengan menggunakan metode UKM Digital Printing Prabu menunjukkan hasil yang lebih rendah dengan besaran angka Rp 13.976,-. Hal ini menciptakan selisih diantara kedua jenis metode perhitungan tersebut, dimana besaran angka selisihnya yaitu sebesar Rp 5.317,-. Selisih terjadi dikarenakan perbedaan cara perhitungan dari kedua jenis metode yang dilakukan. Untuk berdasarkan jenis metode UKM Digital Printing Prabu, mereka hanya memasukkan biaya bahan baku flexi china saja, biaya karyawan/tenaga kerja, dan biaya overhead. Biaya overhead yang digunakan dalam metode UKM Digital Printing Prabu ini hanya biaya listrik saja tanpa memasukkan biaya lainnya kedalam proses perhitungan biaya harga pokok produksi. Hal ini dikarenakan pihak UKM Digital Prinitng Prabu tidak mengetahui bahwa sebenarnya ada biayabiaya lain yang berkaitan dengan proses produksi dan harus dimasukkan kedalam penentuan harga pokok produksi

Sedangkan untuk berdasarkan jenis metode full costing yang telah dilakukan, biaya yang dimasukkan yaitu biaya bahan baku, biaya karyawan/tenaga kerja, dan biaya overhead. Yang membedakannya dari perhitungan berdasarkan metode UKM Digital Printing Prabu adalah di biaya bahan baku ini terdapat biaya flexi china, biaya tinta, biaya lem dan biaya mata ayam. Untuk tenaga kerja karena deksprint bukan bagian produksi maka biaya yang dibebankan ke 
produksi menjadi 2 orang saja yaitu bagian printing dan finishing. Dan untuk overhead ini terdapat lebih dari satu biaya, diantaranya yaitu biaya penyusutan peralatan produksi, biaya listrik, biaya sewa tempat, biaya solven, dan biaya tissue. Sehingga hasil harga pokok produksi yang didapat dari metode full costing ini lebih tinggi dari pada hasil berdasarkan metode UKM Digital Printing Prabu. Dan menyebabkan adanya selisih dari kedua harga pokok produksi tersebut.

\section{Perbedaan Keuntungan yang Didapat Berdasarkan Metode UKM Digital Printing Prabu dan Metode Full Costing}

Untuk menjual hasil cetakannya, UKM Digital Printing Prabu menerapkan harga jual Rp 25.000,- per meter persegi (m2). Dari harga jual yang diterapkan maka akan diketahui perbedaan keuntungan yang didapat oleh pihak UKM Digital Printing Prabu, dari kedua metode perhitungan yang sudah dilakukan. Berikut akan dijelaskan perbedaan keuntungan yang didapat :

Tabel 4. Perbedaan Besaran Keuntungan Yang Didapat

Metode Full Costing

Metode UKM Digital Printing

Prabu

\begin{tabular}{llc}
\hline Harga Jual & Rp 25.000,- & Rp 25.000,- \\
Harga Pokok Produksi & Rp 19.293,- & Rp 13.976,- \\
\hline Keuntungan (harga jual - HPP) & Rp 5.707,- & Rp 11.024,- \\
Presentase Keuntungan & $22,82 \%$ & $44,10 \%$
\end{tabular}

Sumber: UKM Digital Printing Prabu Bulan Januari-Maret 2020 diolah.

Dari hasil perhitungan diatas dapat diketahui perbedaan keuntungan yang didapat. Keuntungan yang didapat berdasarkan metode UKM Digital Printing Prabu lebih besar dibandingkan dengan metode full costing. Dimana keuntungan yang diperoleh berdasarkan metode full costing sebesar Rp 5.707,- dan berdasarkan metode UKM Digital Printing Prabu Rp $11.024,-$.

Sedangkan untuk persentase keuntungan UKM Digital Priting Prabu pada bulan Januari 2020 sampai bulan Maret 2020 berdasarkan metode full costing yaitu sebesar 22,82 \% . Dan berdasarkan metode UKM Digital Printing Prabu sebesar 44,10 \%. Ada selisih sebesar 21,28 \% dari persentase keuntungan yang didapat berdasarkan kedua metode yang diperhitungkan. Jika UKM Digital Printing Prabu tetap ingin mendapatkan keuntungan sebesar 44,10\% dari harga pokok produksi metode full costing maka harga jual yang diberikan kepada customer yaitu sebesar Rp 27.801,- per meter persegi (m2), didapat dari 100\% + 44,10\% (keuntungan) dikali dengan biaya produksi ( $\mathrm{Rp} 19.293)$.

\section{PENUTUP}

\section{Kesimpulan}

Berdasarkan temuan penelitian dan pembahasan yang sudah dilakukan, ada beberapa yang dapat disimpulkan, diantaranya yaitu : 
- Temuan penelitian memperlihatkan bahwa perhitungan harga pokok produksi pada metode Usaha Kecil Menengah Digital Printing Prabu sebesar Rp 13.976,- Dan untuk metode UKM Digital Printing Prabu dalam menentukan harga pokok produksi memasukkan biaya bahan baku hanya flexi china saja, biaya karyawan/tenaga kerja dan overheadnya hanya listrik saja.

- Harga pokok produksi dengan menggunakan metode full costing sebesar Rp 19.293,-Dengan metode full costing biaya yang dimasukkan adalah biaya bahan baku, biaya karyawan/tenaga kerja, dan biaya overhead. Biaya bahan baku diantaranya yaitu biaya flexi china, tinta, lem, dan mata ayam. Untuk biaya tenaga kerja terdapat 2 orang saja yaitu bagian printing dan finishing. Sedangkan untuk overhead dalam metode full costing ini terdapat biaya penyusutan alat produksi, biaya listrik, sewa tempat, solven, dan tissue.

- Penentuan harga pokok produksi berdasarkan metode full costing menunjukkan angka yang lebih besar dari penentuan metode UKM Digital Printing Prabu. Hasil pada penentuan metode full costing yaitu Rp 19.293,-. Sedangkan untuk hasil penentuan pada metode UKM Digital Printing Prabu menunjukkan hasil yang lebih rendah dengan angka Rp 13.976,-. Yang membedakannya dari kedua metode perhitungan tersebut yaitu pada metode UKM Digital Printing hanya memasukkan biaya bahan baku flexi china, biaya tenaga kerja, dan biaya overhead listrik saja. Dan pada metode full costing biaya bahan baku terdapat lebih dari satu biaya diantaranya yaitu biaya flexi china, biaya tinta, biaya lem, dan biaya mata ayam. Untuk biaya tenaga kerja karena deksprint bukan bagian produksi maka biaya yang dibebankan ke produksi menjadi 2 orang saja yaitu bagian printing dan finishing. Sedangkan untuk biaya overhead terdapat biaya penyusutan alatalat produksi, listrik, sewa tempat, solven dan tissue. Sehingga hasil harga pokok produksi yang didapat dari metode full costing ini lebih besar dari hasil metode UKM Digital Printing Prabu. dan Hal ini menciptakan selisih diantara kedua jenis metode perhitungan tersebut, dimana besaran angka selisihnya yaitu sebesar Rp 5.317,--. Dengan harga jual Rp 25.000 maka keuntungan yang diperoleh dari metode UKM Digital Printing Prabu sebesar Rp 11.024,- dan keuntungan yang diperoleh dengan cara full costing adalah Rp 5.707,-. Jika dibuat dalam bentuk presentase maka keuntungan yang diperoleh berdasarkan metode UKM Digital Printing Prabu sebesar 44,10 \%, dan sedangkan metode full costing sebesar $22,82 \%$.

\section{Saran}

UKM Digital Printing Prabu sebaiknya menggunakan metode full costing dalam penentuan harga pokok produksi, dikarenakan metode ini memasukkan seluruh unsur biaya yang dikeluarkan selama proses produksi baik yang bersifat tetap maupun variabel, sehingga informasi yang dihasilkan lebih akurat dibandingkan metode UKM Digital Printing Prabu yang digunakan saat ini, dan harga pokok produksi yang sudah didapat dengan menggunakan metode full costing ini bisa dijadikan masukan UKM Digital Printing Prabu dalam menentukan harga jual serta bisa memaksimalkan keuntungan yang didapat.

\section{REFERENSI}

Batubara, Helmina. (2013). Penentuan harga pokok produksi berdasarkan metode full costing pada pembuatan etalase kaca dan alumunium di ud. Istana alumunium manado. Jurnal emba vol.1 no.3 september 2013, hal. 217-224 issn 2303-1174.

Badan Pusat Statistik (2019) 
Hansen, Don R. dan Maryanne M.Mowen (2019). Akuntansi manajerial, edisi 8 buku 1. Jakarta: Salemba Empat.

Ikatan Akuntan Indonesia. (2016). Standar Akuntansi Keuangan Entitas Mikro, Kecil, dan Menengah. Jakarta : Ikatan Akuntan Indonesia. http://iaiglobal.or.id/v03/files/draft_ed_sak_emkm_kompilasi.pdf

Komara, Bintang. dan Ade Sudarma (2016). Analisis penentuan harga pokok produksi dengan metode full costing sebagai dasar penetapan harga jual pada $\mathrm{cv}$ salwa meubel. Jurnal ilmiah ilmu ekonomi vol. 5 edisi 9, okt 2016, issn 20886969. http://eprints.ummi.ac.id/51/3/Analisis\%20Penentuan\%20Harga\%20Pokok\%2OProduksi \%20Dengan\%20Metode\%20Full\%20Costing\%20Sebagai\%20Dasar\%20Penetapan\%20Har ga\%20Jual\%20Pada\%20CV\%20Salwa\%20Meubel.pdf

Maghfirah, Mifta, dan Fazli Syam BZ (2016). Analisis perhitungan harga pokok produksi dengan penerapan metode full costing pada umkm kota banda aceh. Jurnal ilmiah mahasiswa ekonomi akuntansi (jimeka) vol. 1, no. 2, (2016) halaman 59-70. http://www.jim.unsyiah.ac.id/EKA/article/view/750

Mulyadi (2016). Akuntansi Biaya. Yogyakarta: UPP-STIM YKPN

Pelealu, Axel Johannes Henry. Wilfiried S Manoppo., dan Joanne V Mangindaan (2018). Analisis perhitungan harga pokok produksi dengan menggunakan metode full costing sebagai dasar perhitungan harga jual (studi kasus pada kertina's home industry). Jurnal administrasi bisnis vol.6 no.2 tahun 2018. http://media.neliti.com > publication

Putri, Rahmi Hayati (2015). Penerapan metode full costing dalam penetapan harga pokok produksi untuk menentukan harga jual pada usaha kecil menengah dilampung selatan (studi kasus usaha kecil menengah tahu di daerah natar lampung selatan). Jurnal ilmiah gema ekonomi, vol.5 no. 2 agustus 2015 hal $745-756$. http://ejurnal.stieprasetiyamandiri.ac.id/index.php/gem/article/view/79

Septiawati, Selly (2019). Analisis perhitungan harga pokok produksi berdasarkan metode full costing pada umkm keripik kentang al-mubarok.

Slat, Andre Henri (2013). Analisis harga pokok produk dengan metode full costing dan penentuan harga jual. Jurnal emba vol 1 no3 juni 2013 hal 110-117, issn 23031174. http://ejournal.unsrat.ac.id/index.php/emba/article/view/1638

Sugiyono (2010). Metode penelitian bisnis. Bandung: Alfabeta.

Sujarweni, V.Wiratna (2019). Akuntansi biaya teori \& penerapannya. Yogyakarta : Pustaka Baru Press. 